\title{
Multitasking by Polycomb response elements
}

\author{
Elizabeth S. Jaensch, Sharmistha Kundu, and Robert E. Kingston \\ Department of Molecular Biology, Massachusetts General Hospital, Boston, Massachusetts, 02114, USA
}

\begin{abstract}
Development requires the expression of master regulatory genes necessary to specify a cell lineage. Equally significant is the stable and heritable silencing of master regulators that would specify alternative lineages. This regulated gene silencing is carried out by Polycomb group (PcG) proteins, which must be correctly recruited only to the subset of their target loci that requires lineagespecific silencing. A recent study by Erceg and colleagues (pp. 590-602) expands on a key aspect of that targeting: The same DNA elements that recruit PcG complexes to a repressed locus also encode transcriptional enhancers that function in different lineages where that locus must be expressed. Thus, PcG targeting elements overlap with enhancers.
\end{abstract}

Polycomb group (PcG) proteins are conserved in most eukaryotic organisms-spanning plants, flies, and mammals -and are primarily grouped into Polycomb-repressive complex 1 (PRC1) and PRC2. These complexes are targeted to repressed loci by PcG response elements (PREs). Unraveling the complexities of PcG targeting, which is essential to understanding mammalian development and several human developmental disorders and cancers, is complicated by the dual function of PRE sequences in both repression and activation (Erceg et al. 2017). As has been thoroughly reviewed recently (Bauer et al. 2016), the complex interactions between different PcG complexes make the elucidation of rules for PcG targeting even more difficult. Here, we focus on studies that characterize PREs and their functions in Drosophila and describe how lessons learned in this powerful model system relate to the ongoing quest to understand mammalian PRE targeting.

In some studies, the identification of PRE sequences has been misled by an overreliance on what is now known to be an oversimplified functional paradigm: PRC2 methylates histone $\mathrm{H} 3$ on Lys27 (H3K27me3), and PRC1 is then recruited to its target by recognizing $\mathrm{H} 3 \mathrm{~K} 27 \mathrm{me} 3$ via its chromodomain-containing subunit. The belief

[Keywords: Polycomb response elements (PREs); pleiohomeotic repressive complex (PhoRC); developmental enhancers; spatio-temporal expression; transcriptional repression; silencing; embryonic development] Corresponding author: kingston@molbio.mgh.harvard.edu

Article is online at http://www.genesdev.org/cgi/doi/10.1101/gad.303206. 117. that this is a universal pathway has led to the faulty notion that mapping H3K27me3-enriched sites will map PREs. However, there are multiple forms of PRC1, some of which bind target loci independently of H3K27me3 (Farcas et al. 2012; Tavares et al. 2012; Blackledge et al. 2014). Thus, H3K27me3 is not necessary to define a PRE. There are also numerous sites in the genome where $\mathrm{H} 3 \mathrm{~K} 27 \mathrm{me} 3$ is present on genes that are still expressed (e.g., "bivalent" promoters) (Bernstein et al. 2006; Ku et al. 2008), indicating that H3K27me3 is also not sufficient for targeting gene silencing. While H3K27me3 is known to be essential for proper PcG function in flies (Pengelly et al. 2013), measuring it alone can yield only a partial picture of PcG function and targeting and must be augmented by other analyses.

Differences in the cellular contexts and organization of PcG-repressed loci further complicate establishing universal rules for the identification of PREs. For example, the $H O X$ gene loci in flies and mammals encode several key homeotic regulators and are central to development. $H O X$ genes are distributed in a characteristic pattern that reflects where they function along the body axis to determine anterior-posterior patterning. Expression of a transgene reporter fused to a PRE from the fly Hox cluster $B X-C$ results in varying "strengths" of a remembered repressive chromatin state that appear to differ according to anatomical position and hence the cell-specific cast of activators (Coleman and Struhl 2017). This indicates that the ability of the $B X-C$ PRE to establish a heritable repressive state is dependent on surrounding signals. This analysis also adds further complexity to the role for $\mathrm{H} 3 \mathrm{~K} 27 \mathrm{me} 3$ in targeting gene silencing that is maintained across cell division, the hallmark of PREs. Methylated H3K27 is not sufficient to encode robust memory, as methylation and hence silencing are diluted through cell division (Coleman and Struhl 2017; Laprell et al. 2017). Other analyses, based on mutation of components of the PRC1 complex, show that the $B X-C$ PRE differs in PRC1 requirement from other PREs in the fly genome (Kahn et al. 2016).Thus, PRE function can differ based on local

(C) 2017 Jaensch et al. This article is distributed exclusively by Cold Spring Harbor Laboratory Press for the first six months after the full-issue publication date (see http://genesdev.cshlp.org/site/misc/terms.xhtml). After six months, it is available under a Creative Commons License (Attribution-NonCommercial 4.0 International), as described at http:// creativecommons.org/licenses/by-nc/4.0/. 
environment and can depend on different PcG interactions at the PRE. Therefore, in flies, there is no universal model to explain PRE function; extant data imply that this is likely as complex, if not more so, in mammals.

These considerations mean that defining PcG targeting and PRE function must go beyond identifying genomic locations of methylation and specific PcG factors. We need to understand not only the cross-talk between disparate PcG members but also the local interfaces with activating factors. Readouts for the repressed state in specific organismal locations (i.e., specific tissue types) during development are required to unravel PRE function and determine which specific factors define the function of a specific PRE in its endogenous genomic location. This is most readily accomplished in Drosophila, where the ability of a PRE to function can be measured in different tissues during development via the expression of a reporter transgene.

A recent study (Erceg et al. 2017) used reporter transgenes to examine numerous sequences that have PRE function in Drosophila. The findings offered a dramatic extension of previous work that suggested that PRE sequences either overlap with or are in close proximity to sequences that activate transcription. Specifically, elements that function as PREs also guide the action of Trithorax group proteins, which function in transcriptional activation (Ringrose and Paro 2007). In this new study, known developmental enhancers such as $U b x_{-}$BXD-C were fused to a mini-white reporter, and, upon knockdown of $p h$, tissue-specific repression was lost, and the enhancer became active in new cell types. In turn, a number of known PREs, including $b x$, were sufficient to activate expression of a lac $Z$ reporter in specific tissues. Thus, the same DNA element can provide silencing in one part of the organism and activation in another (Fig. 1).

Why might there be an overlap between PRE function and enhancer sequences? There are mechanistic advantages that might have driven the evolution of this arrangement. The first advantage is simple: If an element is needed to stably repress an enhancer, what better place to locate it than immediately adjacent to, or interspersed with, that enhancer? This simplifies interaction and presumably also provides exclusiveness or strengthens the impact of the regulatory mechanism due to proximity. However, there are hints of more complicated cross-talk in which the repressing and activating components might coordinate to generate more efficient function. For example, both activation by enhancers and repression by the PcG proteins are known to involve higher-order

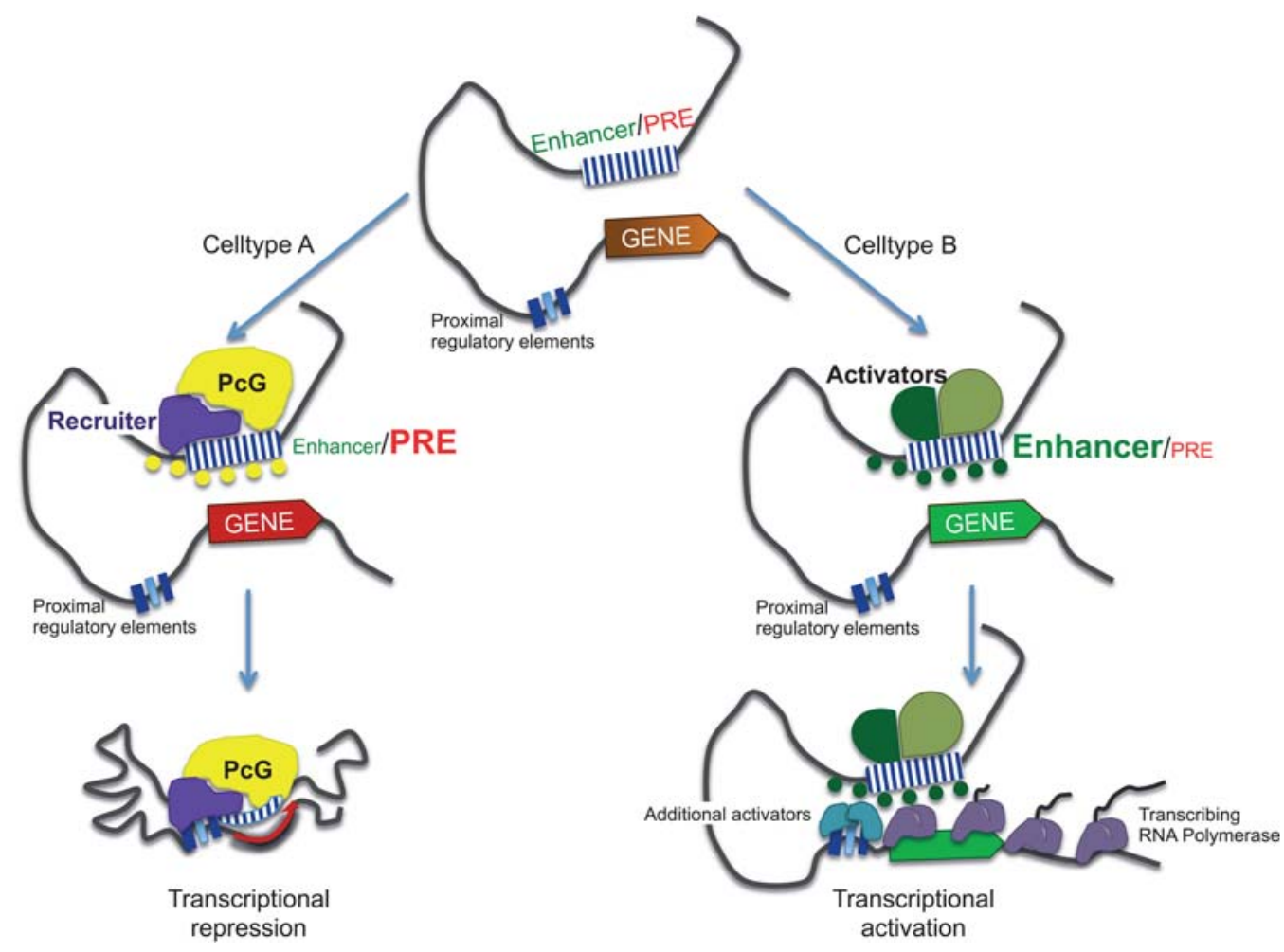

Figure 1. Cis-regulatory elements with dual activity facilitate cell type specificity and dynamic regulation of gene expression. DNA elements can act as enhancers or PREs to provide spatiotemporal context to gene regulation during embryonic development. A regulatory element could be bound by PhoRC (in flies) or other recruiters such as YY1 (in mammals), which would in turn recruit PcG complexes and repress the target gene. The same regulatory element could instead be bound by lineage-specific transcriptional activators in a different cell type, thereby leading to expression of that target gene. In cell type A, PcG binding causes compaction of the locus and repression of the target gene. In contrast, activators are recruited to the dual enhancer/PRE in cell type B. This triggers a different chain of events, such as binding of additional downstream activators, transcription by RNA polymerase II, and chromatin loops between the target gene and its regulatory elements. 
interactions that place distant regions adjacent to one another by either looping or forming discrete domains of interaction (Deng et al. 2012; Williamson et al. 2012; Kundu et al. 2017). There have been suggestions that PcG-mediated looping might help with driving activating interactions (Cruz-Molina et al. 2017). Another area of mechanistic overlap involves the necessity of altering chromatin structure to facilitate binding by the full complement of factors that are needed to generate a PRE or an enhancer. Mechanisms that facilitate the binding of activating proteins to enhancers in chromatin might also be co-opted to facilitate binding of PcG factors.

There is evidence for similar functional overlap in mammals. For example, there are sequences that have been shown to have both PRE and enhancer functions in different cell lineages of mouse embryos (van Arensbergen et al. 2017). Activating and repressing elements frequently overlap in mammals, as has also been observed in Drosophila (Rickels et al. 2016). For example, noncanonical $\mathrm{PRC1}$ is recruited to active genes in leukemic stem cells (van den Boom et al. 2016). Thus, overlap of sequences and possible duality in mechanistic function are also seen in mammals, indicating that these might represent a general set of phenomena. This complicates the current paradigm that PREs drive only repression and that enhancers drive only activation.

There are lessons in this complex interplay for those characterizing PRE function in mammals. The first involves a technical challenge; it is clear from analysis in flies that the most informative measures of PRE function are done in the developing organism. There have been studies of PRE function using cell culture systems and reporter genes in mammals (Woo et al. 2013; van Arensbergen et al. 2017), but even these are cumbersome. Analysis of PRE function in, for example, an intact developing mouse embryo, would be analogous to what has been useful in flies but has significant technical barriers that might be addressed with the application of CRISPR and reporter gene methodologies. A second inference is that PREs might be distinguished from other sequences by the presence of covalent modifications that reflect both activation and repression. It is known that a subset of GC-rich sequences associates with PRE function in mammals; a recent study proposed, based on analogy to Drosophila, that the presence of MLL2-deposited methylation of Lys4 of histone $\mathrm{H} 3$ might be an indicator of "true" PRE function. This raises the possibility that duality of function might be used to help with PRE prediction (Rickels et al. 2016).

Scientists like to pigeonhole mechanisms into simplified models. However, appropriate maintenance of repression and activation is central to proper animal development and hence requires robust and probably redundant mechanisms that are multilayered and complex. Forcing simplified models on such complex processes and assuming that the same regulatory rules apply in every setting can be misleading. A tractable number of overlapping mechanisms for regulating developmental genes appear to be emerging. Learning how these might inter- face not only will yield interesting insights into biology but might also give rise to methodologies for specifically impacting regulation that have therapeutic use. Understanding the cross-talk between complexes that maintain repression and those that maintain activation-the yinyang of development-appears to be a key area for increased analysis.

\section{Acknowledgments}

We thank the National Institute of General Medical Sciences for supporting PcG work in our laboratory (GM048405 and GM043901, both to R.E.K.).

\section{References}

Bauer M, Trupke J, Ringrose L. 2016. The quest for mammalian Polycomb response elements: are we there yet? Chromosoma 125: 471-496.

Bernstein BE, Mikkelsen TS, Xie X, Kamal M, Huebert DJ, Cuff J, Fry B, Meissner A, Wernig M, Plath K, et al. 2006. A bivalent chromatin structure marks key developmental genes in embryonic stem cells. Cell 125: 315-326.

Blackledge NP, Farcas AM, Kondo T, King HW, McGouran JF, Hanssen LL, Ito S, Cooper S, Kondo K, Koseki Y, et al. 2014. Variant PRC1 complex-dependent H2A ubiquitylation drives PRC2 recruitment and polycomb domain formation. Cell 157: 1445-1459.

Coleman RT, Struhl G. 2017. Causal role for inheritance of H3K27me3 in maintaining the OFF state of a Drosophila HOX gene. Science 356: eaai8236.

Cruz-Molina S, Respuela P, Tebartz C, Kolovos P, Nikolic M, Fueyo R, van Ijcken WFJ, Grosveld F, Frommolt P, Bazzi H, et al. 2017. PRC2 facilitates the regulatory topology required for poised enhancer function during pluripotent stem cell differentiation. Cell Stem Cell 20: 689-705.e9.

Deng W, Lee J, Wang H, Miller J, Reik A, Gregory PD, Dean A, Blobel GA. 2012. Controlling long-range genomic interactions at a native locus by targeted tethering of a looping factor. Cell 149: 1233-1244.

Erceg J, Pakozdi T, Marco-Ferreres R, Ghavi-Helm Y, Girardot C, Bracken AP, Furlong EM. 2017. Dual functionality of cis-regulatory elements as developmental enhancers and Polycomb response elements. Genes Dev 31: 590-602.

Farcas AM, Blackledge NP, Sudbery I, Long HK, McGouran JF, Rose NR, Lee S, Sims D, Cerase A, Sheahan TW, et al. 2012. KDM2B links the Polycomb repressive complex 1 (PRC1) to recognition of CpG islands. Elife 1: e00205.

Kahn TG, Dorafshan E, Schultheis D, Zare A, Stenberg P, Reim I, Pirrotta V, Schwartz YB. 2016. Interdependence of PRC1 and PRC2 for recruitment to Polycomb Response Elements. Nucleic Acids Res 44: 10132-10149.

$\mathrm{Ku}$ M, Koche RP, Rheinbay E, Mendenhall EM, Endoh M, Mikkelsen TS, Presser A, Nusbaum C, Xie X, Chi AS, et al. 2008. Genomewide analysis of PRC1 and PRC2 occupancy identifies two classes of bivalent domains. PLoS Genet 4: e1000242.

Kundu S, Ji F, Sunwoo H, Jain G, Lee JT, Sadreyev RI, Dekker J, Kingston RE. 2017. Polycomb repressive complex 1 generates discrete compacted domains that change during differentiation. Mol Cell 65: 432-446 e435. 
Jaensch et al.

Laprell F, Finkl K, Muller J. 2017. Propagation of Polycomb-repressed chromatin requires sequence-specific recruitment to DNA. Science 356: 85-88.

Pengelly AR, Copur O, Jackle H, Herzig A, Muller J. 2013. A histone mutant reproduces the phenotype caused by loss of histone-modifying factor Polycomb. Science 339: 698-699.

Rickels R, Hu D, Collings CK, Woodfin AR, Piunti A, Mohan M, Herz HM, Kvon E, Shilatifard A. 2016. An evolutionary conserved epigenetic mark of Polycomb response elements implemented by Trx/MLL/COMPASS. Mol Cell 63: 318-328.

Ringrose L, Paro R. 2007. Polycomb/Trithorax response elements and epigenetic memory of cell identity. Development 134: 223-232.

Tavares L, Dimitrova E, Oxley D, Webster J, Poot R, Demmers J, Bezstarosti K, Taylor S, Ura H, Koide H, et al. 2012. RYBPPRC1 complexes mediate H2A ubiquitylation at polycomb target sites independently of PRC2 and H3K27me3. Cell 148: 664-678. van Arensbergen J, Dussaud S, Pardanaud-Glavieux C, GarciaHurtado J, Sauty C, Guerci A, Ferrer J, Ravassard P. 2017. A distal intergenic region controls pancreatic endocrine differentiation by acting as a transcriptional enhancer and as a polycomb response element. PLoS One 12: e0171508.

van den Boom V, Maat H, Geugien M, Rodriguez Lopez A, Sotoca AM, Jaques J, Brouwers-Vos AZ, Fusetti F, Groen RW, Yuan H, et al. 2016. Non-canonical PRC1.1 targets active genes independent of H3K27me3 and is essential for leukemogenesis. Cell Rep 14: 332-346.

Williamson I, Eskeland R, Lettice LA, Hill AE, Boyle S, Grimes GR, Hill RE, Bickmore WA. 2012. Anterior-posterior differences in HoxD chromatin topology in limb development. Development 139: 3157-3167.

Woo CJ, Kharchenko PV, Daheron L, Park PJ, Kingston RE. 2013. Variable requirements for DNA-binding proteins at polycomb-dependent repressive regions in human HOX clusters. Mol Cell Biol 33: 3274-3285. 


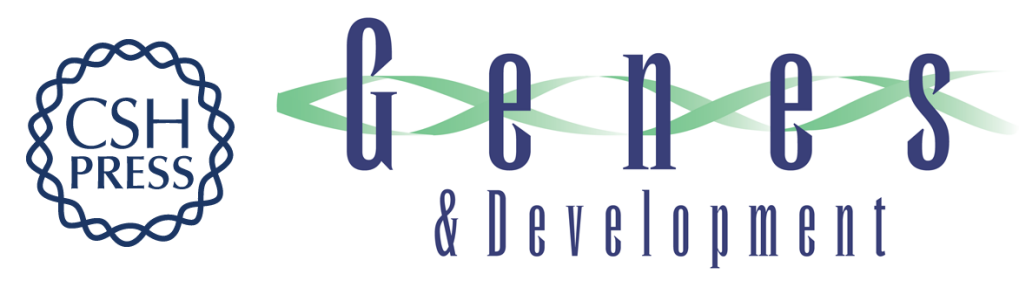

\section{Multitasking by Polycomb response elements}

Elizabeth S. Jaensch, Sharmistha Kundu and Robert E. Kingston

Genes Dev. 2017, 31:

Access the most recent version at doi:10.1101/gad.303206.117

References This article cites 20 articles, 7 of which can be accessed free at: http://genesdev.cshlp.org/content/31/11/1069.full.html\#ref-list-1

Creative This article is distributed exclusively by Cold Spring Harbor Laboratory Press for the first Commons six months after the full-issue publication date (see License http://genesdev.cshlp.org/site/misc/terms.xhtml). After six months, it is available under a Creative Commons License (Attribution-NonCommercial 4.0 International), as described at http://creativecommons.org/licenses/by-nc/4.0/.

Email Alerting Receive free email alerts when new articles cite this article - sign up in the box at the top Service right corner of the article or click here.

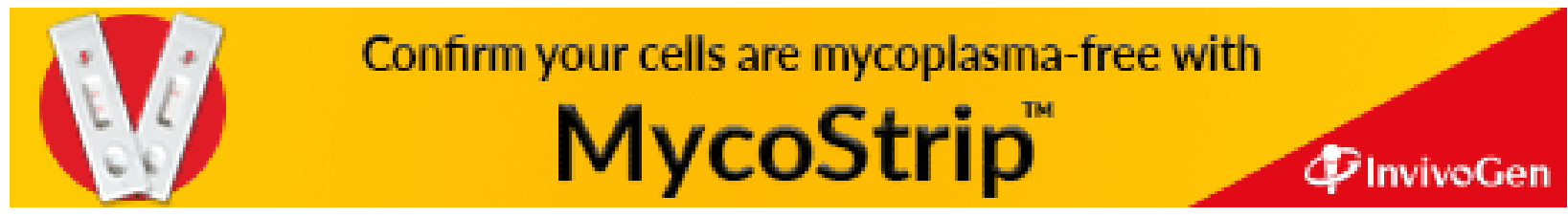

